\title{
Strategi Pemasaran Madu Hutan di Kota Bengkulu
}

\author{
Marketing Strategy of Forest Honey in Bengkulu City
}

\author{
M. Nurrahmi, R. Saepudin, dan B. Zain \\ Jurusan Peternakan, Fakultas Pertanian, Universitas Bengkulu \\ Jalan Raya W. R. Supratman, Kandang Limun, Bengkulu, 38371 A \\ Email : mutianurrahmi18@gmail.com
}

\begin{abstract}
This study aims to analyze the marketing strategy of forest honey in Bengkulu City, by first identifying, assessing the internal and external factors that affect the company. This research was conducted by survey method (observation and questioner) with consumer of honey at various outlets. The data obtained in the form of honey consumer segmentation analysis using descriptive analysis, and marketing test are analyzed by SWOT analysis method that includes Strength and Weaknesses as well as Opportunity and Threat factors. Based on the analysis, the tools used to compile the strategic factors of the business is to use SWOT matrix. This matrix can clearly illustrate how external opportunities and threats facing the company can be tailored to the internal strengths and weaknesses of the business. Based on SWOT analysis results obtained, it is known that marketing honey in Bengkulu City is in quadrant $\mathrm{I}$ is a very favorable situation and support aggressive strategy. This can be seen from the weighted total weight of the company's strengths and weaknesses of 1.71 , and the probability and threat factor of 0.9 . This illustrates that existing marketing strategies can be improved.
\end{abstract}

Key words: Dorsata, marketing strategy, SWOT

\begin{abstract}
ABSTRAK
Penelitian ini bertujuan untuk menganalisis strategi pemasaran madu hutan di Kota Bengkulu, dengan terlebih dahulu mengidentifikasi, menilai faktor-faktor internal dan eksternal yang mempengaruhi perusahaan tersebut. Penelitian ini dilakukan dengan metode survey (pengamatan dan kuesioner) dengan konsumen madu pada berbagai outlet. Data yang diperoleh berupa analisis segmentasi konsumen madu dengan menggunakan analisis deskriptif, serta uji pemasaran dianalisis dengan metode analisis SWOT yang mencakup faktor Internal kekuatan (Strenght) dan kelemahan (Weaknesses) serta faktor Eksternal peluang (Opportunity) dan ancaman (Threat). Berdasarkan analisis tersebut, alat yang di pakai untuk menyusun faktor-faktor strategis usaha adalah dengan menggunakan matrik SWOT. Matrik ini dapat menggambarkan secara jelas bagaimana peluang dan ancaman eksternal yang di hadapi perusahaan dapat disesuaikan dengan kekuatan dan kelemahan internal yang dimiliki usaha tersebut. Hasil analisis SWOT yang diperoleh, dapat diketahui pada pemasaran madu di Kota Bengkulu berada pada kuadran I merupakan situasi yang sangat menguntungkan dan mendukung strategi agresif. Hal ini dapat di lihat dari besarnya total tertimbang dari faktor kekuatan dan kelemahan perusahaan sebesar 1,71, dan faktor peluang dan ancaman sebesar 0,9. Hal ini menggambarkan bahwa strategi pemasaran yang ada dapat ditingkatkan.
\end{abstract}

Kata kunci : Dorsata, strategi pemasaran, SWOT

\section{PENDAHULUAN}

Indonesia sangat cocok untuk usaha peternakan lebah, karena negara Indonesia sangat kaya akan ragam tanaman berbunga dan hasil pertanian yang dapat dimanfaatkan sebagai sumber pakan lebah, sehingga dapat diusahakan sepanjang tahun. Pada musim berbunga tiba, maka produksi nektar pakan lebah berlimpah. Selain itu Indonesia memiliki hutan alam yang sangat luas, sekitar 143 juta hektar dengan beraneka ragam jenis pohon berbunga penghasil nektar dan tepung sari. Dengan potensi sumber daya hutan yang cukup luas di Indonesia, membuat Indonesia memiliki keunggulan dibandingkan negara lain. 
Pembangunan ekonomi di Indonesia harus di tingkatkan dengan memanfaatkan keunggulan sumber daya hutan yang ada sehingga dapat menjadi keunggulan bersaing dan bisa menjadi pendorong bagi pertumbuhan perekonomian nasional secara umum (Novandra, 2013).

Madu hutan dihasilkan oleh lebah liar (Apis dorsata), yaitu jenis lebah yang belum dapat dibudidayakan. Umumnya lebah tersebut hidup secara alami di hutan Sumatra, Kalimantan, Sulawesi, Jawa dan kepulauan Nusa Tenggara dan merupakan jenis lebah yang penting bagi perlebahan Indonesia karena kontribusinya berupa produksi madu yang cukup tinggi serta pemanfaatannya sangat potensial dijadikan sebagai sumber mata pencaharian masyarakat sekitar hutan (Gultom, 2007). Pengembangan pemanfaatan madu hutan dinilai mampu melestarikan hutan Indonesia karena pengelolaannya dilakukan secara tradisional (Zent, 2009).

Madu merupakan salah satu produk perlebahan yang sudah lama dikenal oleh masyarakat di dunia, termasuk Indonesia. Indonesia dengan jumlah penduduk saat ini hampir mencapai 240 jiwa, merupakan penduduk terbesar ke-4 di dunia membutuhkan madu yang cukup banyak. Menurut Pusat Perlebahan Nasional (2008), Indonesia memiliki tingkat konsumsi madu sekitar 15 gram/kapita/tahun, sedangkan di negaranegara maju seperti Jerman, Jepang, Inggris, dan Prancis tingkat konsumsi madu telah mencapai 700-1.500 gram/kapita/tahun. Rendahnya konsumsi madu antara lain disebabkan karena banyaknya masyarakat menganggap bahwa madu hanya bermanfaat sbagai obat, sehingga tingkat konsumsi masyarakat Indonesia terhadap madu masih sangat rendah.

Madu memiliki pangsa pasar yang luas dan prospek yang baik sehingga banyak pemburu lebah madu berkompetisi dalam persaingan dibidang usaha ternak lebah madu. Produkproduk hasil lebah sangat menjanjikan jika digunakan sebagai peluang usaha. Melihat potensi yang dimiliki Indonesia serta melihat banyaknya manfaat dan khasiat madu maka pemerintah sejak awal tahun 70-an telah melakukan usaha budidaya lebah madu. Menurut data Departemen Kehutanan Republik Indonesia (2009), saat ini telah berkembang ratusan lebah lokal, baik yang dikelola dalam skala besar maupun skala kecil sebagai usaha sampingan. Banyaknya pesaing dalam memproduksi madu menyebabkan pengembangan madu serta pemasaran madu harus mampu menciptakan nilai tambah (added value) dari produknya sehingga mampu bersaing dengan produsen lain. Nilai tambah ini dapat dilakukan oleh produsen dengan menghasilkan produk yang berkualitas tinggi, kemasan terbaik, higenis sesuai dengan selera dan keinginan konsumen (Rosalina, 2010 ).

Belum terjaminnya kualitas madu oleh pemburu yang banyak dijual di pasaran membuat masyarakat menjadi ragu dan kurang percaya untuk membeli madu terutama dalam menentukan keaslian sebuah produk madu. Harga madu pun sangat bervariasi bila dilihat dari jenis maupun asal daerahnya. Hal ini akan menyebabkan kepercayaan masyarakat terhadap produk madu semakin berkurang. Permasalahan yang muncul di tingkat petani adalah serapan teknologi pengolahan dan pemasaran produk yang masih rendah. Hal ini 
berdampak pada harga jual produk, karena produk yang dibuat harus dapat memenuhi kepuasan konsumen (Suranto, 2005). Madu murni yang dihasilkan di tingkat petani biasanya tidak melalui pengolahan yang baik dan hygienis, sudah terkontaminasi dan tampilan produk (packaging) nya pun juga tidak menarik sehingga akan berpengaruh terhadap keputusan pembelian pada konsumen madu murni di Kota Bengkulu (Rosalina, 2010).

Melihat kondisi tersebut maka suatu studi mengenai perilaku konsumen terhadap madu dapat digunakan sebagai dasar dalam pengambilan keputusan oleh pelaku bisnis. Hal ini dapat dijadikan sebagai solusi bagi peternak dan pelaku bisnis madu dalam rangka meningkatkan volume pemasaran produknya. Dalam hal ini kondisi yang paling sulit adalah mempertahankan konsumen untuk selalu menggunakan produk unggulannya dengan menciptakan loyalitas bagi pelanggan dengan menjaga ketersediaan dan konsistensi kualitas produk madu. Penerapan strategi pemasaran yang tepat dibutuhkan untuk dapat meningkatkan jumlah penjualan produk di pasar, memaksimalkan keuntungan, meningkatkan pangsa pasar serta meningkatkan pembangun ekonomi masyarakat. Salah satu strategi pemasaran yang biasa digunakan banyak perusahaan adalah konsep 4P/ marketing mix (bauran pemasaran) yang terdiri atas produck (produk), price (harga), promotion (promosi) dan place (tempat) (Kotler dan Keller, 2006). Dengan demikian, faktor yang ada dalam bauran pemasaran (marketing mix) merupakan variabel produk/atribut yang dipandang penting oleh konsumen dan dijadikan sebagai dasar dalam proses pengambilan keputusan pembelian.

Berdasarkan uraian diatas maka rumusan permasalahan yang dapat dikemukakan dalam penelitian ini yaitu strategi apa yang harus diterapkan dalam rangka pengembangan produk madu. Adapun tujuan penelitian ini adalah menganalisis strategi pemasaran madu hutan di Kota Bengkulu.

\section{MATERI DAN METODE}

Pengambilan data dilakukan selama satu bulan dari bulan November sampai bulan Desember 2017. Penentuan lokasi penelitian ini dilakukan pada outlet-outlet (Al - Fatih, Al - Mujtahid, Herbal, Madu Rawa Makmur, Salsabila, Giant dan Apotek Paten) madu di Kota Bengkulu pemilihan dilakukan dengan cara purposive (sengaja). Adapun alat yang digunakan pada waktu pelaksanaan penelitian ini berupa kuesioner, kamera dan alat pendukung lainnya.

\section{Metode Penentuan Sampel dan Responden}

Dalam penelitian ini jumlah responden sebanyak 32 responden untuk diwawancarai. Sebelumnya angket digunakan sebanyak 2 angket untuk terlebih dahulu diwawancarai dan dikonsultasi dengan 2 orang expert (ahli lebah), termasuk didalamnya untuk menentukan bobot dan rating setiap atribut baik internal maupun eksternal. Didalam angket dapat menjadi nilai penting didalam perhitungan SWOT, 30 angket disebarkan kepada responden yang dipilih secara purposive (sengaja) yang terdiri dari produsen, pengecer dan konsumen.

\section{Metode Pengambilan Data}

Data yang diambil dalam penelitian ini adalah berupa data primer dan data sekunder: Data primer, yaitu data yang langsung dan 
sengaja diperoleh dari sumber data oleh peneliti untuk tujuan yang khusus (Surakhmad, 1998). Data primer dalam penelitian ini adalah data yang diperoleh dari responden secara langsung oleh peneliti dengan memberikan pertanyaan secara terstruktur pada alat bantu kuesioner, wawancara dan melalui pengamatan (observasi) di lapangan. Data yang diambil yaitu mengenai alasan dan faktor yang mempengaruhi pembelian madu yang dikonsumsi oleh konsumen.

Data sekunder adalah data yang telah dahulu diperoleh dari orang diluar penelitian sendiri sebagai pembanding. Data sekunder yang dibutuhkan berupa data yang meliputi madu lokal hingga nasional serta literatur lainnya.

\section{Metode Analisis Data}

Data yang diperoleh dalam penelitian bertujuan untuk (1) menganalisis segmentasi konsumen madu dengan menggunakan analisis deskriptif. (2) uji pemasaran dengan menggunakan analisis SWOT. Analisis deskriptif ini digunakan untuk menggambarkan karakteristik konsumen dan tahapan proses keputusan pembelian madu di Kota Bengkulu yang diperoleh melalui kuesioner. Analisis deskriptif menggunakan tabel frekuensi yaitu penyajian data dan informasi dalam bentuk tabel sederhana yang berisi pengelompokkan jawaban yang sama. Hasil yang diperoleh kemudian dipersentasekan berdasarkan jumlah responden. Persentase terbesar dari setiap hasil adalah faktor dominan dari masing-masing variabel yang dianalisis.

Analisis SWOT merupakan analisis atas keadaan internal usaha meliputi kekuatan (strength) dan kelemahan (weakness), keadaan eksternal yang meliputi peluang (opportunity) dan ancaman (threath), Analisis SWOT pada dasarnya ditunjukan untuk mengembangkan atau untuk memandu usaha penjualan madu menuju masa depan.

Alat yang dipakai untuk menyusun faktor-faktor strategis adalah matrik SWOT.

Tabel 1. Matriks SWOTIFAS (Internal Faktor Analisis Summary) dan EFAS (Eksternal Faktor Analisis Summary)

\begin{tabular}{|c|c|c|}
\hline EFAS IFAS & $\begin{array}{l}\text { STRENGTH (S) } \\
\text { Menentukan 2- } 10 \text { faktor- } \\
\text { faktor kekuatan internal }\end{array}$ & $\begin{array}{l}\text { WEAKNESESS (W) } \\
\text { Menentukan 2- } 10 \text { faktor- } \\
\text { faktor kelemahan internal }\end{array}$ \\
\hline $\begin{array}{l}\text { OPPORTUNITY }(\mathrm{O}) \\
\text { Menentukan 2- } 10 \text { faktor- } \\
\text { faktor peluang eksternal }\end{array}$ & $\begin{array}{l}\text { STRATEGI - SO } \\
\text { Menciptakan strategi yang } \\
\text { menggunakan kekuatan } \\
\text { untuk memanfaatkan } \\
\text { peluang }\end{array}$ & $\begin{array}{l}\text { STRATEGI - WO } \\
\text { Menciptakan strategi yang } \\
\text { meminimalkan kelemahan } \\
\text { untuk memanfaatkan } \\
\text { peluang }\end{array}$ \\
\hline $\begin{array}{l}\text { THREATH (T) } \\
\text { Menentukan 2- } 10 \text { faktor- } \\
\text { faktor ancaman eksternal }\end{array}$ & $\begin{array}{l}\text { STRATEGI - ST } \\
\text { Menciptakan strategi yang } \\
\text { menggunakan kekuatan } \\
\text { untuk mengatasi ancaman }\end{array}$ & $\begin{array}{l}\text { STRATEGI - WT } \\
\text { Menciptakan strategi yang } \\
\text { meminimalkan kelemahan } \\
\text { dan menghindari ancaman }\end{array}$ \\
\hline
\end{tabular}


Menurut Rangkuti (2009), pembagian faktor eksternal (EFAS) tersebut dapat dilihat ruang dalam dalam analisis SWOT dengan pada gambar diagram analisis SWOT: penilaian terdapat faktor internal (IFAS) dan

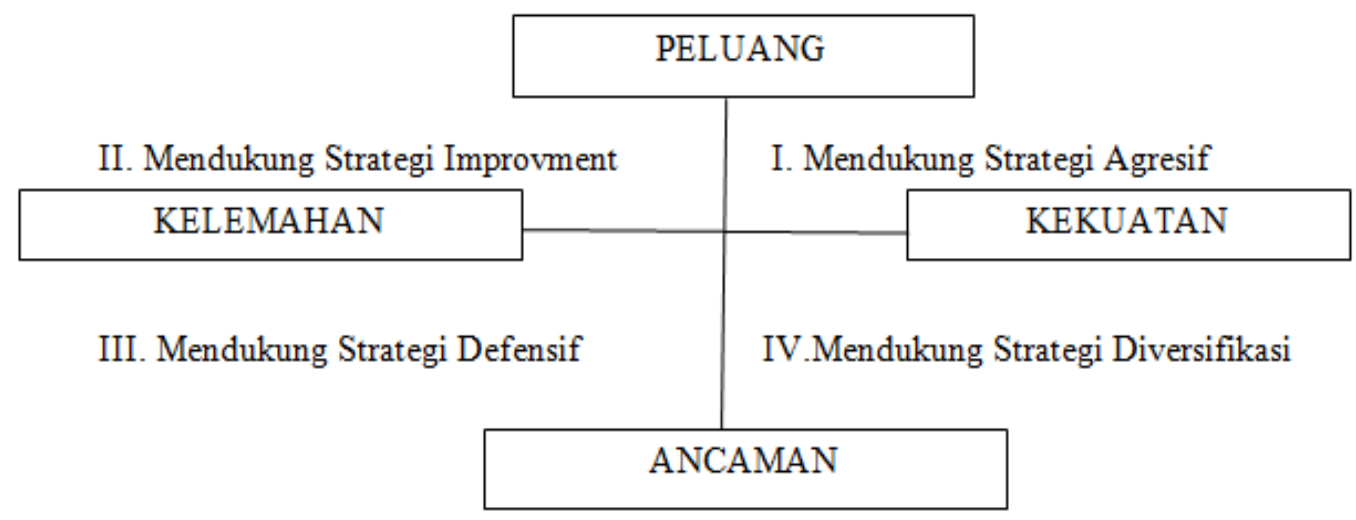

Gambar 1. Diagram Analisis SWOT

Diagram analisis SWOT diatas yang harus diterapkan adalah menggunakan menunjukan posisi kuadrat I, II, III, dan IV kekuatan untuk memanfaatkan peluang jangka yaitu:

Kuadrat I, merupakan situasi yang sangat menguntungkan. Sektor dan sub sektor tersebut memiliki peluang dan kekuatan sehingga dapat memanfaatkan peluang yang ada. Strategi yang harus di terapkan dalam kondisi ini adalah mendukung kebijakan pertumbuhan yang agresif (growth oriented strategy).

Kuadrat II, sektor dan sub sektor tersebut memiliki peluang pasar yang sangat besar, tetapi dilain pihak menghadapi beberapa kendala/kelemahan internal. Fokus strateginya adalah meminimalkan masalah-masalah internal sehingga dapat merebut peluang pasar lebih baik.

Kuadrat III, merupakan situasi yang sangat tidak menguntungkan, pengembangan sektor dan sub sektor tersebut menghadapi berbagai ancaman dan kelemahan internal.

Kuadrat IV, meskipun menghadapi beberapa ancaman sektor dan sub sektor ini masih memiliki kekuatan dari segi internal. Strategi panjang dengan cara strategi diversifikasi (produk/pasar).

\section{HASIL DAN PEMBAHASAN}

Gambaran Umum Perdagangan dan Karaktersistik Responden Madu Hutan Kota Bengkulu

Sub sektor perdagangan merupakan leading sector di Kota Bengkulu dan pengaruhnya cukup besar terhadap roda perekonomian kota. Barang-barang yang diperdagangkan tidak hanya berasal dari wilayah Propinsi Bengkulu, tetapi berasal dari luar Propinsi, seperti Jakarta, Lampung, Palembang dan Kota lainnya. Sebagai leading sektor di dalam perekonomian Kota Bengkulu, sub sektor ini seharusnya lebih didorong lagi agar perannya meningkat terus.

Kebutuhan madu dunia diperkirakan mencapai 1,4 juta ton pertahun merupakan pasar yang besar dan akan meningkat terus seiring dengan pola hidup sehat back to nature sebagai minuman kesehatan, karena madu 
terbukti dapat memelihara kesehatan, meningkatkan kekebalan, menjaga kebugaran dan meningkatkan vitalitas tubuh (Saepudin, 2013).

Di tingkat petani harga madu sangat bervariasi, tidak ada kesepakatan harga dasar madu, sehingga harga dapat dimainkan oleh pengumpul dan dapat merugikan petani madu itu sendiri. Madu berkualitas baik terkadang dihargai sama dengan madu yang berkualitas buruk. Jika ingin dipasarkan untuk keperluan industri harus memenuhi standar SNI 19-04281998, antara lain kadar air yang diperkenankan maksimal 22\%, padahal kadar air madupada saat di panen dari sarang sekitar 25- 28\% (tergantung musim) dan umumnya petani pengumpul tidak memiliki alat pengolahan madu untuk menurunkan kadar air dan langsung dijual kepada konsumen atau kepada pedagang pengumpul (Saepudin, 2013).

Berdasarkan laporan penelitian Aliansi Organis Indonesia, harga madu dipasar Internasional hanya US\$ 2,-/kg, lebih rendah dibanding denganharga madu organis di dalam negeri yang bisa mencapai Rp. 50.000,-/Kg (Sri, 2015). Peluang pasar madu dalam negeri maupun internasional sangat terbuka lebar, terbukti dengan jumlah impor sebesar 2.438 ton setara dengan nilai Rp. 95.837.412.000,pada tahun 2012 dan sebesar 2.177 ton setara dengan nilai Rp. 110.823.441.500 pada tahun 2013,- (Fahrudin, 2016). Indonesia dengan luas kawasan hutan 130,68 juta hektar dan tenaga kerja yang besar sangat potensial untuk pengembangan lebah madu. Budidaya lebah madu di Indonesia masih belum berkembang terbukti dengan produksi rata-rata madu pertahun hanya sekitar 2.000 ton, dan 90\% produksi tersebut berasal dari madu alam (Fahrudin, 2016).

Karakteristik umum konsumen madu hutan dapat dilihat melalui hasil jawaban kuesioner dari resonden. Pada hasil penelitian ini karakteristik konsumen yang diamati meliputi: jenis kelamin, usia, status pekerjaan, status pernikahan, status pendidikan dan total pengeluaran rutin per bulan untuk mengkonsumsi madu.

Konsumen yang membeli madu mayoritas berjenis kelamin perempuan, karena perempuan lebih selektif dalam pengambilan keputusan pembelian suatu produk. Teori yang dikemukakan oleh Lury (1998) yaitu bahwa $80 \%$ atau lebih keputusan pembelian atau konsumsi barang ditentukan oleh perempuan. Konsumen yang berusia antara 25-40 tahun lebih mendominasi karena umumnya pada usia tersebut konsumen lebih berfikir logis dan rasional dalam menentukan produk yang bermanfaat untuk kesehatan. Pada umumnya konsumen yang berusia dewasa cenderung memiliki tingkat yang cukup tinggi terhadap produk kesehatan, salah satunya adalah madu yang memiliki banyak manfaat dan kesehatan.

Pada karakteristik status pernikahan konsumen madu hutan adalah yang berstatus sudah menikah. Konsumen yang sudah menikah relatif lebih berhati-hati dalam melakukan pembelian terhadap suatu produk. Untuk status pekerjaan konsumen berstatus pegawai swasta dan pegawai negeri sipil (PNS) lebih mendominasi. Mayoritas konsumen madu hutan di Kota Bengkulu memiliki pendidikan Diploma dan S1, karena menunjukan tingkat pengetahuan konsumsi dalam produk madu. 


\section{Pembobotan}

Pembobotan pada lingkungan internal tingkat kepentingannya didasarkan pada besarnya pengaruh faktor strategisnya, sedangkan pada lingkungan eksternal didasarkan pada kemungkinan memberikan dampak terhadap faktor strategisnya (Rangkuti, 2002). Dalam penententuan nilai dari masingmasing pertanyaan dilakukan pembobotan yang dilakukan dengan bantuan ahli madu. Setiap pertanyaan diberi bobot yang sesuai menurut penilaian ahli dan memiliki kapasitas bobot untuk penilaian masing-masing outlet dengan penyebaran kuesioner kepada konsumen madu ditiap outlet. Dalam kuesioner terdapat 27 pertanyaan, dari 27 pertanyaan tersebut diberi point yang nantinya akan dihitung kembali dengan cara kali silang 1-27 pertanyaan. Perkalian ini akan menghasilkan jumlah total dari 27 pertanyaan tersebut, selanjutnya data dibagi per masingmasing jumlah total, yang hasilnya akan digunakan untuk memberi bobot dari pertanyaan $1-27$.

Pembobotan pada faktor strategis internal (IFAS) bobot tertinggi pada faktor strategis kekuatan berada pada madu asli merupakan madu pilihan utama yaitu sebesar 0,10 dan faktor strategis kelemahan bobot tertinggi berada pada bentuk promosi dan informasi kurang jelas dan kurang dimengerti sehingga mempengaruhi minat pembelian madu yaitu sebesar 0,05 dan bobot terendah berada pada faktor madu asli merupakan madu yang dijual botolan di pinggiran jalan yaitu sebesar 0,005. Bobot tersebut dapat dilihat pada Tabel 3.

Pembobotan pada faktor strategis eksternal (EFAS) bobot tertinggi pada faktor peluang berada pada beralihnya penggunaan obat-obatan kimia ke obat-obatan alami dan herbal termasuk madu yaitu bobot sebesar 0,25 dan bobot tertinggi faktor pada strategis ancaman berada pada terdapat madu yang berasal dari luar Kota Bengkulu sebesar 0,18. Bobot tersebut dapat dilihat pada Tabel 4.

\section{Analisis SWOT Untuk Menentukan Strategi Pemasaran Madu di Kota Bengkulu \\ Strategi pemasaran madu hutan di Kota} Bengkulu ditentukan dengan analisis SWOT. Menurut Rangkuti (2015) SWOT merupakan singkatan dari lingkungan internal Strenghts dan Weaknesses serta lingkungan eksternal Opportunities dan Threats yang di hadapi dunia bisnis. Faktor-faktor internal (kekuatan dan kelemahan) serta faktor eksternal (peluang dan ancaman) dalam hal strategi pemasaran madu di Kota Bengkulu, dapat di lakukan identifikasi dan evaluasi untuk mengetahui kemampuan internal yang dimiliki guna menentukan strategi untuk memanfaatkan peluang yang ada dan secara bersamaan menghindari ancaman.

Analisis SWOT berguna untuk mengetahui posisi dan kesesuaian strategi saat ini, strategi saat ini sesuai dengan kemamuan yang ada serta mengantisipasi persoalan yang kemungkinan dapat muncul pada masa yang akan datang. Untuk merumuskan alternatif strategi pemasaran madu di Kota Bengkulu yang terkandung didalamnya maka dilakukan pendekatan melalui analisis SWOT.

Hal terpenting yang terlebih dahulu dilakukan dalam analisis SWOT adalah menentukan besarnya bobot masing-masing item pertanyaan. Besarnya bobot ditetapkan berdasarkan tingkat kepentingan masing- 
masing item pertanyaan dalam setiap variabel faktor penentu dalam lingkungan strategis yang ada dengan melihat kekuatan, kelemahan, peluang dan anaman. Semakin besar kekuatan dan peluangnya maka nilai rating-nya akan semakin tinggi dan baik semakin kecil kekuatannya dan peluangnya maka semakin rendah rating-nya.

Rating pada analisis SWOT ditentukan oleh pendapat para ahli atau dengan FGD (Focus Group Discussion). Nilai rating pada faktor strategis internal dan eksternal yang memiliki rating tertinggi 4 yaitu adanya manfaat kesehatan dari produk membuat konsumen tertarik untuk membeli madu, memberikan pelayananan penjelasan yang mendetail tentang produk, produsen dan peternak madu memperoleh madu dari hutan atau diternakkan, dan gaya hidup sehat akan meningkatkan konsumsi madu. Nilai rating dapat dilihat pada Tabel 3 dan 4.

\section{Matriks IFAS (Internal Factor Analisys Summary)}

Lingkungan internal yang telah dianalisis dapat diidentifikasi berupa faktor strategis internal, yaitu kekuatan dan kelemahan. Faktor strategis internal yang telah diidentifikasi dapat diberikan bobot dan rating. Pemberian bobot pada tiap-tiap faktor kekuatan dan kelemahan. Setelah pemberian bobot dilakukan langkah selanjutnya adalah pemberian rating ini menunjukan bahwa faktor kekuatan mana yang lebih baik diantara beberapa kekuatan dan faktor kelemahan mana yang lebih lemah diantara beberapa kelemahan.

Tabel 3. Faktor Strategi Internal (IFAS)

\begin{tabular}{|c|c|c|c|c|c|}
\hline & $\begin{array}{l}\text { ktor Strategis } \\
\text { Strength / Kekuatan }\end{array}$ & Bobot & Rating & $\begin{array}{l}\text { Nilai } \\
\text { (skor) }\end{array}$ & Prioritas \\
\hline $\mathrm{a}$ & $\begin{array}{l}\text { Adanya mafaat kesehatan dari produk membuat } \\
\text { konsumen tertarik untuk membeli madu }\end{array}$ & 0,09 & 4 & 0,36 & 1 \\
\hline $\mathrm{b}$ & $\begin{array}{l}\text { Merek dan kualitasnya baik mempengaruhi } \\
\text { loyalitas konsumen terhadap madu }\end{array}$ & 0,09 & 4 & 0,34 & 2 \\
\hline $\mathrm{c}$ & Madu asli merupakan pilihan utama & 0,10 & 3 & 0,29 & 3 \\
\hline $\mathrm{d}$ & $\begin{array}{l}\text { Anda merupakan penikmat dan pengkonsumsi } \\
\text { madu }\end{array}$ & 0,08 & 3 & 0,23 & 5 \\
\hline $\mathrm{e}$ & $\begin{array}{l}\text { Anda merasa puas dengan pedagang madu dan } \\
\text { memutuskan untuk menjadi pelanggan }\end{array}$ & 0,06 & 1 & 0,06 & 10 \\
\hline $\mathrm{f}$ & $\begin{array}{l}\text { Keasliannya produk ditunjukan dengan adanya } \\
\text { label }\end{array}$ & 0,02 & 2 & 0,04 & 12 \\
\hline $\mathrm{g}$ & Harga yang ditawarkan sesuai dengan kualitasnya & 0,08 & 2 & 0,16 & 7 \\
\hline $\mathrm{h}$ & Persediaan dan kontinuitasnya ada sepanjang waktu & 0,05 & 3 & 0,14 & 8 \\
\hline $\mathrm{i}$ & $\begin{array}{l}\text { Bentuk promosi dan informasi mempengaruhi } \\
\text { pembeliaan madu }\end{array}$ & 0,06 & 3 & 0,19 & 6 \\
\hline & $\begin{array}{l}\text { memberikan pelayanan dan penjelasan yang } \\
\text { mendetail tentang produk }\end{array}$ & 0,07 & 1 & 0,07 & 9 \\
\hline
\end{tabular}


$\mathrm{k}$ Produsen dan peternak madu memperoleh madu dari hutan atau diternakkan

Memberikan banyak variasi madu

$\begin{array}{llll}0,07 & 4 & 0,27 & 4\end{array}$

Sub Total Kekuatan

$\begin{array}{llll}0,02 & 2 & 0,05 & 11\end{array}$

2. Weaknesess / Kelemahan

0,78

2,19

a Melihat orang lain membeli dan gaya hidup membuat konsumen tertarik untuk membeli madu

Bobot

$\begin{array}{llll}0,04 & 2 & 0,08 & 3\end{array}$

b Pengaruh orang lain dan harga mempengaruhi loyalitas konsumen terhadap madu

0,04

3

$0,11 \quad 1$

c selain mengkonsumsi madu untuk diri sendiri anda juga menjual madu yang telah anda beli

$\begin{array}{llll}0,01 & 2 & 0,02 & 7\end{array}$

d Harga terjangkau adalah salah satu pilihan dibandingkan dengan produk bermerek

$\begin{array}{llll}0,01 & 2 & 0,03 \quad 6\end{array}$

e Madu asli merupakan madu yang dijual botolan dipinggir jalan

$\begin{array}{llll}0,005 & 2 & 0,01 \quad 8\end{array}$

$\mathrm{f}$

Bentuk promosi dan informasi kurang jelas dan

kurang dimengerti sehingga mempengaruhi minat

0,05

2

0,10 pembelian madu

g Dalam memberikan pelayanan dan penjelasan pedagang kurang mendetail tentang produk

$\begin{array}{llll}0,03 & 2 & 0,06 & 4 \\ & & & \\ 0,04 & 1 & 0,04 & 5 \\ 0,23 & & 0,45 & \\ 1,00 & & 2,64 & \end{array}$

Keterangan : Penilaian Rating menggunakan Skala 1-4

Berdasarkan pada Tabel 3. terlihat bahwa faktor lingkungan internal yaitu kekuatan dan kelemahan sebagai faktor strategis, maka diperoleh hasil perhitungan pada Tabel diatas menunjukkan bahwa adanya manfaat kesehatan dari produk membuat konsumen tertarik untuk membeli madu merupakan kekuatan utama bagi strategi pemasaran madu hutan di Kota Bengkulu dengan nilai skor sebesar 0,36 faktor kekuatan utama ini didukung oleh madu asli merupakan madu pilihan utama dengan nilai skor sebesar 0,29 . Hal ini konsumen madu menghendaki madu asli disetiap pembelian madu sehingga konsumen percaya akan produk tersebut dan memiliki loyalitas yang tinggi dalam membeli serta mengkonsumsi madu setiap harinya.
Penolakan terjadi karena mutu madu yang dinilai tidak baik, seperti adanya kaki lebah dan kotoran sarang lebah. Namun menurut ukuran industri mutunya tidak memenuhi standar, penawaran harganya lebih rendah dibandingkan penjualan langsung ke konsumen lokal (Sri, 2015).

Faktor yang menjadi kelemahan utama adalah bentuk promosi dan informasi yang kurang jelas dan kurang dimengerti sehingga mempengaruhi minat pembelian madu dengan skor sebesar 0,10. Faktor kelemahan ini hendaknya dapat diatasi dengan cara melakukan peningkatan promosi dan informasi melalui event-event penjualan sehingga konsumen dapat tertarik membeli dan mengkonsumsi madu. Menurut Tjiptono 
(2008) promosi merupakan bentuk komunikasi tidak langsung, yang didasari pada informasi tentang keunggulan atau keuntungan suatu produk, yang disusun sedemikian rupa sehingga menimbulkan rasa menyenangkan yang akan mengubah pikiran seseorang untuk melakukan pembelian.

\section{Matrik EFAS (Internal Factor Analisys}

\section{Summary)}

Lingkungan eksternal yang telah dianalisis dapat diidentifikasi berupa faktor Tabel 4. Faktor Strategi Eksternal (EFAS)

\begin{tabular}{|c|c|c|c|c|}
\hline $\begin{array}{l}\text { Faktor Strategis } \\
\text { 3. Opportunity / Peluang }\end{array}$ & Bobot & Rating & $\begin{array}{l}\text { Nilai } \\
\text { (skor) }\end{array}$ & Prioritas \\
\hline $\begin{array}{l}\text { a Gaya hidup sehat akan meningkatkan konsumsi } \\
\text { madu }\end{array}$ & 0,21 & 4 & 0,85 & 1 \\
\hline $\begin{array}{l}\text { b Beralihnya penggunaan obat-obatan kimia ke } \\
\text { obat-obatan alami dan herbal termasuk madu }\end{array}$ & 0,25 & 3 & 0,74 & 2 \\
\hline c Akses pasar makin terjangkau & 0,07 & 1 & 0,07 & 4 \\
\hline $\begin{array}{l}\text { d Sulitnya mencari madu asli karena tidak ada } \\
\text { produsen yang membudidayakan lebah } \\
\text { madu/mencari ke hutan }\end{array}$ & 0,11 & 3 & 0,32 & 3 \\
\hline Sub Total & 0,64 & & 1,98 & \\
\hline 4. Threats / Ancaman & Bobot & Rating & $\begin{array}{l}\text { Nilai } \\
\text { (skor) }\end{array}$ & Prioritas \\
\hline a Harga madu di pasar fluktuatif & 0,05 & 2 & 0,09 & 3 \\
\hline $\begin{array}{l}\text { b Terdapat madu yang berasal dari luar Kota } \\
\text { Bengkulu }\end{array}$ & 0,18 & 4 & 0,71 & 1 \\
\hline $\begin{array}{l}\text { c Tingkat kepercayaan adanya madu asli yang } \\
\text { rendah }\end{array}$ & 0,14 & 2 & 0,28 & 2 \\
\hline Sub Total & 0,36 & & 1,08 & \\
\hline TOTAL & 1,00 & & 3,06 & \\
\hline
\end{tabular}
Faktor strategis eksternal yang telah diidentifikasi dapat diberikan bobot dan rating. Pemberian bobot pada tiap-tiap faktor peluang dan ancaman. Setelah pemberian bobot dilakukan langkah selanjutnya adalah pemberian rating ini menunjukan bahwa faktor peluang mana yang lebih baik diantara beberapa peluang dan faktor ancaman mana yang lebih kuat diantara beberapa ancaman.
Faksternal, yaitu peluang dan ancaman.

Keterangan: Penilaian Rating Menggunakan Skala 1-4

Berdasarkan pada Tabel 4. terlihat bahwa lingkungan faktor eksternal yaitu faktor strategis peluang dan ancaman, serta diberikan bobot dan rating, maka diperoleh hasil perhitungan pada tabel diatas menunjukan bahwa gaya hidup sehat akan meningkatkan konsumsi madu merupakan peluang utama bagi strategi pemasaran madu hutan di Kota Bengkulu dengan nilai skor sebesar 0,85.

Dengan adanya gaya hidup sehat maka akan mendorong peluang bagi konsumen untuk mengkonsumsi madu pengaruh konsumen sebagai individu dalam pengambilan keputusan meliputi kebutuhan konsumen, persepsi konsumen terhadap 
karakteristik yang terdapat pada produk, faktor demografi, gaya hidup, dan karakter pribadi konsumen (Assael, 1992).

Faktor yang menjadi ancaman utama bagi strategi pemasaran madu terdapat madu yang berasal dari luar Kota Bengkulu dengan nilai skor sebesar 0,71. Ancaman tersebut timbul karena masuknya industri baru yang akan bersaing memperebut pangsa pasar. Pendatang baru pada suatu industri membawa kapasitas baru, keinginan untuk merebut bagian pasar, serta seringkali juga sumber daya yang besar. Akibatnya harga dapat menjadi turunatau biaya membengkak sehingga mengurangi kemampulabaan (Porter et al., 1992).

Berdasarkan perhitungan yang telah dilakukan melalui matriks IFAS dan EFAS analisis SWOT, maka didapatkan nilai akhir dari faktor-faktor internal yaitu kekuatan dan kelemahan, serta faktor-faktor eksternal yaitu peluang dan ancaman (Wulandari, 2009) seperti yang ditujukan pada Tabel 5. Dengan perolehan sebagai berikut:

Tabel 5. Rekapitulasi hasil perhitungan kekuatan, kelemahan, peluang dan ancaman

\begin{tabular}{llcl}
\hline No & Uraian & Nilai & Selisih \\
\hline 1. & Faktor Internal & & \\
Kekuatan & 2,15 & 1,71 \\
& Kelemahan & 0,44 & \\
& Faktor Eksternal & & \\
2. & Peluang & 1,98 & \\
& Ancaman & 1,08 & 0,9
\end{tabular}

Berdasarkan hasil perhitungan yang telah dilakukan melalui analisis SWOT, maka didapatkan nilai akhir dari faktor-faktor internal yaitu kekuatan dan kelemahan, serta faktor-faktor eksternal yaitu peluang dan ancaman. Berdasarkan hasil rekapitulasi pada
Tabel 5.diatas selisih pada faktor internal yaitu besar 1,71 dan untuk selisih pada faktor eksternal yaitu 0,9 maka strategi keseluruhan dapat diketahui dengan menggunakan peluang sebaik-baiknya, mencoba meminimalisir kelemahan, menggunakan tingkat kekuatan sebagai modal utama dasar serta menekan ancaman yang ada pada outlet tersebut.

Matriks SWOT digunakan untuk menentukan alternatif strategi pemasaran usaha penjualan madu yang dapat diterapkan oleh outlet-outlet yang berada di Kota Bengkulu. Matriks SWOT dapat menggambarkan secara jelas bagaimana peluang dan ancaman eksternal yang akan dihadapi oleh outlet usaha penjualan madu sehingga dapat disesuaikan dengan kekuatan dan kelemahan internal.

Matriks ini menghasilkan 4 sel kemungkinan alternatif strategi, yaitu strategi SO (Strength - Opportunity), strategi WO (Weaknesses - Opportunity), strategi WT (Weaknesses - Threath) dan strategi ST (Strength - Threath). (Tabel 6).

Strategi S-O: strategi yang menggunakan kekuatan usaha outlet madu di Kota Bengkulu untuk memanfaatkan peluang.

Strategi S-T: strategi menggunakan kekuatan usaha outlet madu di Kota Bengkulu untuk menghindari atau mengurangi dampak ancaman.

Strategi W-O: strategi yang bertujuan untuk memperbaiki kelemahan dengan memanfaatkan peluang.

Strategi W-T: strategi yang bersifat defensif yang diarahkan untuk mengurangi kelemahan dan menghindari ancaman. 
Tabel 6. Matrik SWOT IFAS (Internal Faktor Analisis Summary) - EFAS (Eksternal Faktor Analisis Summary)

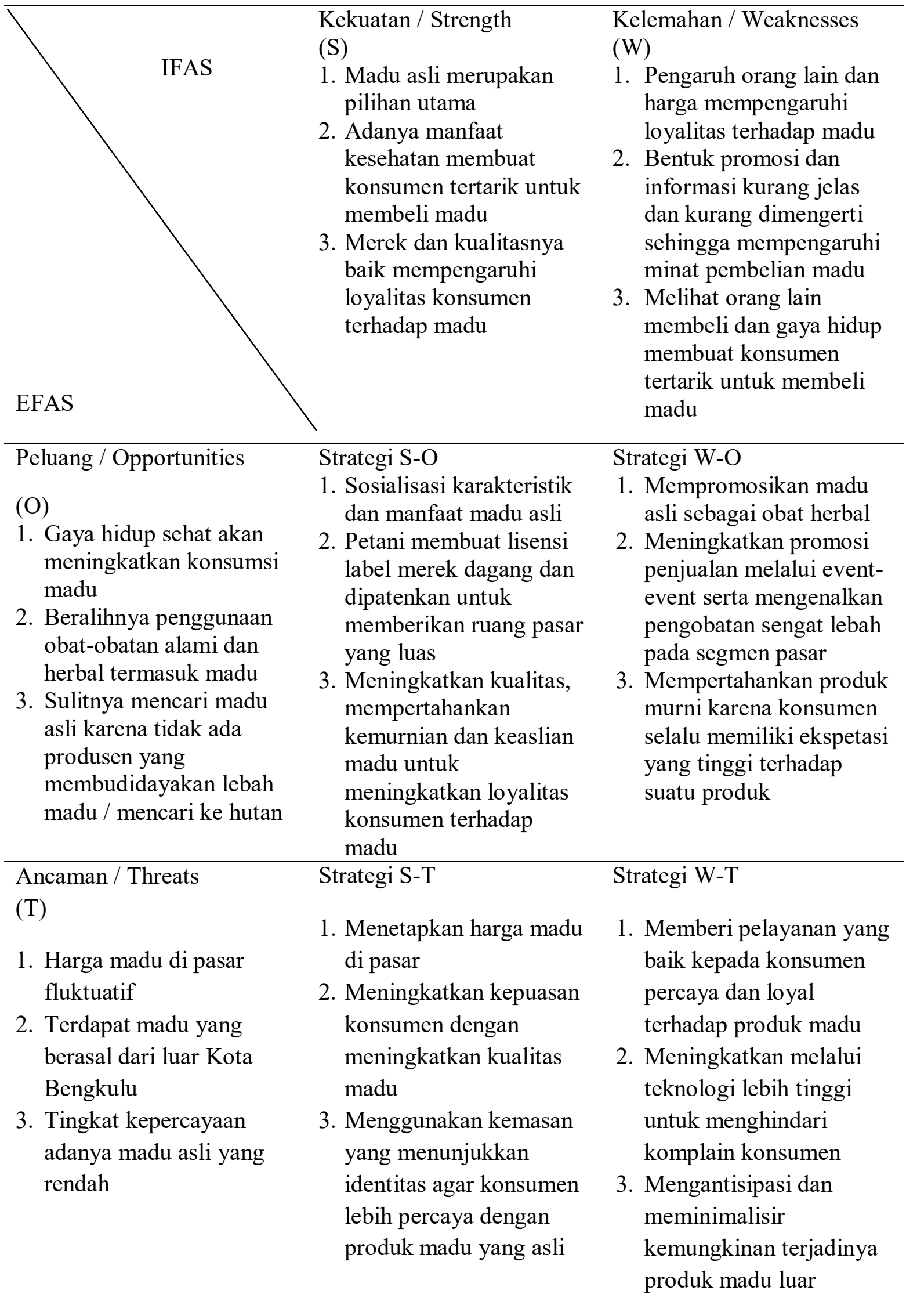


Berdasarkan Tabel 6. Hasil analisis matriks SWOT tabel tersebut merupakan tabel untuk mencari strategi yang akan digunakan untuk faktor internal dan eksternal dalam strategi pemasaran madu hutan di Kota Bengkulu, adapun nilai IFAS untuk faktor kekuatan dan kelemahan didapatkan masingmasing 3 kriteria pertanyaan. Pertanyaan ini diambil melalui tahap penjumlahan total dari faktor pettanyaan kekuatan dan kelemahan, adapun pertanyaan yang diambil yaitu pertanyaan yang memilki skor tertinggi 1 sampai 3 pertanyaan dengan tujuan pertanyaan ini akan mewakili semua pertanyaan yang ada didalam faktor kekuatan dan kelemahan. Pertanyaan dari matrik EFAS diambil dari jumlah faktor peluang dan ancaman dengan kriteria skor tertinggi 1 sampai 3 pertanyaan, dengan tujuan pertanyaan tersebut juga akan mewakili semua pertanyaan yang ada didalam faktor peluang dan ancaman.

Adapun alternatif strategi yang dapat diterapkan yang diambil dari semua aspek yang mendukung antara lain:

Strategi Strength - Opportunity (Strategi SO):

1. Sosialisasi karakteristik dan manfaat madu asli

2. Petani membuat lisensi label merek dagang dan dipatenkan untuk memberikan ruang pasar yang luas

3. Meningkatkan kualitas, mempertahankan kemurnian dan keaslian madu untuk meningkatkan loyalitas konsumen terhadap madu

Dari ketiga strategi tersebut diharapkan untuk pemasaran madu hutan di Kota Bengkulu agar kedepannya lebih baik dan memanfaatkan pasar yang luas atau dapat bersaing dengan madu yang memiliki kemasaran modern.

Strategi Weaknesses - Opportunity (Strategi WO): mempromosikan madu asli sebagai obat herbal, meningkatkan promosi penjualan melalui event-event serta mengenalkan pengobatan sengat lebah pada segmen pasar, dan mempertahankan produk murni karena konsumen selalu memiliki ekspetasi yang tinggi terhadap suatu produk. Dari ketiga strategi WO tersebut untuk pemasaran madu (Apis dorsata) di Kota Bengkulu dengan menggunakan promosi dan informasi dapat menarik perhatian konsumen untuk mengkonsumsi madu.

Strategi Strength - Threats (Strategi ST): menetapkan harga madu di pasar, meningkatkan kepuasan konsumen dengan meningkatkan kualitas produk, dan menggunakan kemasan yang menunjukkan identitas agar konsumen lebih percaya dengan produk madu yang asli. Strategi ST tersebut dapat digunakan dengan meningkatkan kualitas produk dan tetap menjaga keaslian madu.

Strategi Weaknesses - Threath (Strategi WT): memberi pelayanan yang baik kepada konsumen agar konsumen percaya dan loyal terhadap produk madu, meningkatkan melalui teknologi lebih tinggi untuk menghindari komplain konsumen, mengantisipasi dan meminimalisir kemungkinan terjadinya produk madu luar. Strategi WT digunakan jika dikemudian hari keadaan pemasaran madu berada pada situasi yang tidak menguntungkan, pengembangan sektor dan sub sektor tersebut menghadapi berbagai ancaman dan kelemahan internal. 


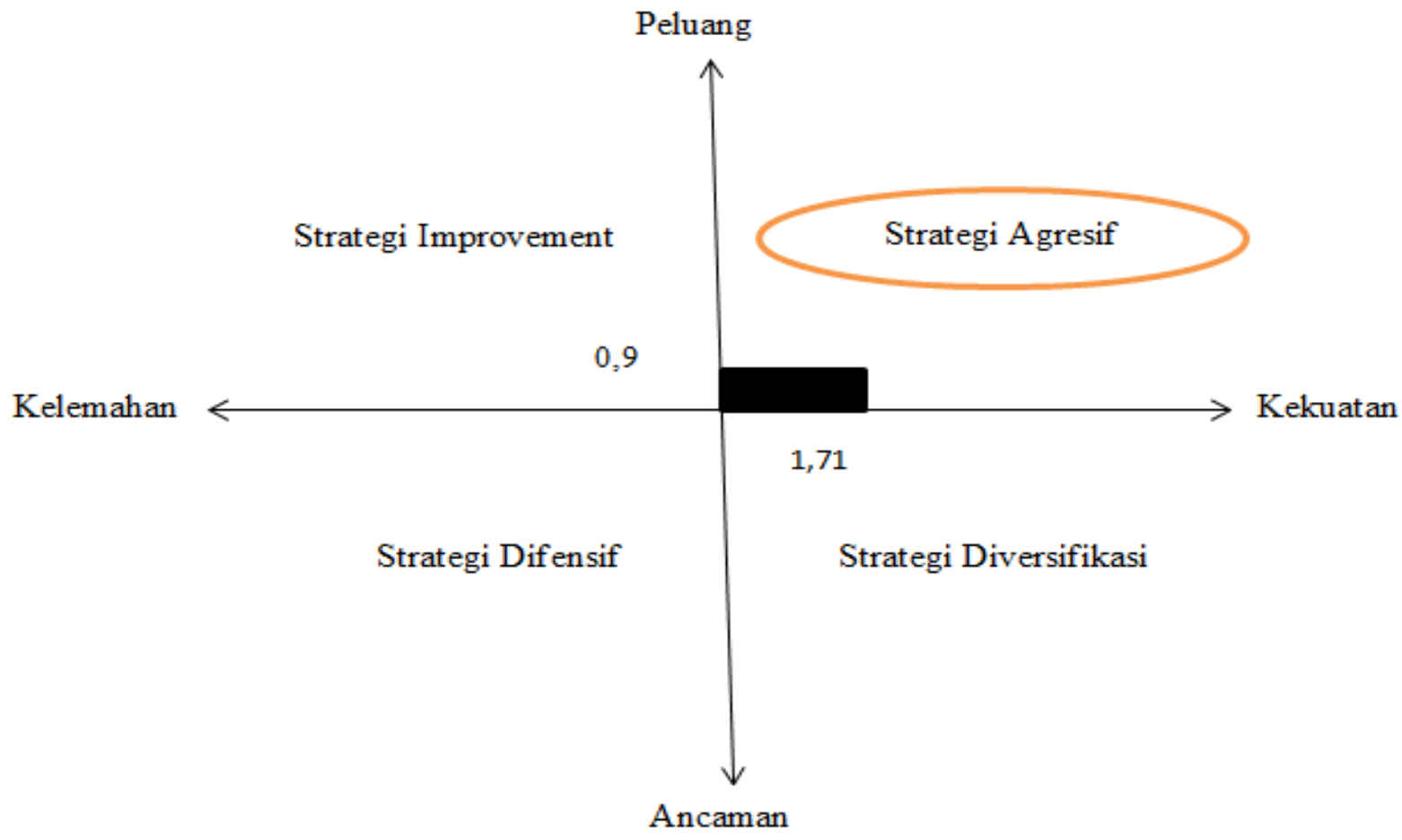

Gambar 2. Diagram Analisis SWOT posisi kuadran outlet madu di Kota Bengkulu

Berdasarkan Gambar 2. menunjukan bahwa posisi pemasaran madu di Kota Bengkulu terletak pada kuadran I yaitu posisi Agresif hal ini dapat diartikan peluang memberikan indikasi pemasaran yang berada pada keadaan menguntungkan karena memiliki peluang dan kekuatan yang lebih besar daripada kelemahan dan ancaman. Artinya strategi pemasaran tersebut dapat memanfaatkan peluang yang ada dengan memaksimalkan kekuatan yang dimiliki. Strategi yang harus dilakukan dalam rangka usaha pemasaran madu (Apis dorsata) di Kota Bengkulu yaitu dengan mendukung kebijakan yang agresif (growth oriented strategy) atau menggunakan strategi Strength - Opportunity (Strategi SO).

\section{KESIMPULAN}

Berdasarkan hasil penelitian dan analisis SWOT menunjukan bahwa peternakan lebah madu dapat dikembangkan secara
Agresif. Strategi yang penting dilakukan untuk mengembangkan pemasaran madu adalah memanfaatkan pasar yang luas atau dapat bersaing dengan madu yang memiliki kemasan modern; menggunakan promosi dan informasi agar menarik perhatian konsumen untuk mengkonsumsi madu; meningkatkan kualitas produk dan tetap menjaga keaslian madu; mengantisipasi dan meminimalisir kemungkinan terjadinya produk madu luar.

\section{DAFTAR PUSTAKA}

Assael, H. 1992. Consumer Behaviour and Marketing Action. Fourth Edition. PWS Kent Publishing Company, Boston.

Departemen Kehutanan Direktorat Jenderal Planologi Kehutanan. 2009. Eksekutif Data Strategis Kehutanan 2009. Jakarta: Departemen Kehutanan RI.

Fahrudin, A. 2016. Potensi dan Pemasaran Madu. Magister Agribisnis. Universitas Bengkulu, Bengkulu. 
Gultom, S. M. P. 2007. Analisis biaya pengusahaan lebah madu pada perlebahan puspa alas roban di Gringsing, Kabupaten Batang Jawa Tengah [skripsi]. Bogor (ID): Institut Pertanian Bogor, Bogor.

Kotler, P. dan K. L. Keller. 2006. Manajemen Pemasaran Jilid 1. PT. Macana Jaya Cemerlang.

Lury, 1998. Peran Karakteristik Merek, dan Karakteristik Hubungan Pelanggan. Jurnal Manajemen. 6 (1): 1-8

Novandra, A dan I. W. Made,. 2013 Peluang pasar produk perlebahan indonesia. Balai Penelitian, Jakarta.

Pusat Perlebahan Nasional, 2008. Lebah madu, cara beternak dan pemanfaatannya. PS, Jakarta.

Rangkuti, F 2002. Analisis SWOT teknik membedah kasus bisnis. PT. Gramedia Pustaka Utama, Jakarta.

Rangkuti, F. 2009. Analisis SWOT teknik membedah kasus bisnis. Gramedia Pustaka Utama, Jakarta.

Rangkuti, F. 2015. Personal SWOT analisis peluang di balik setiap kesulitan. PT. Gramedia Pustaka Utama, Jakarta.

Rosalina, Y. Alnopri, Prasetyo. 2010. Disain kemasan untuk meningkatkan nilai tambah madu bunga kopi sebagai produk unggulan daerah. Jurnal Agroindustri. 2 (1): 1-6.

Saepudin, R. 2013. Lebah budidaya berbasis kawasan. Pertelon Media. Bengkulu.

Sri, N. 2015. Status dan pasar madu organis nasional dan internasional. Aliansi Organis Indonesia. Bogor.

Surakhmad, W. 1998. Pengantar penelitian ilmiah dan dasar metode teknik. Tarsito. Bandung.

Suranto, A. M. Riza. 2005. Penentuan strategi pemasaran berdasarkan perilaku konsumen dengan metode diskriminasi. Jurnal Ilmiah Teknik Industri. 4 (1) : $18-27$.

Tjiptono, F. 2008. Pemasaran Strategik. CV Andi Offset, Yogyakarta.

Wulandari, J. 2009. Strategi Pengembangan. Universitas Indonesia. Jakarta.

Zent, S. 2009. Methodology for developing a vitality index of traditional enviromental knowledge (VITEK) for the project : global indicators of the status and trends of linguistic diversity and traditional knowlwdge. [diunduh 2017 Oktober 26]. Tersedia pada : http://www.terralingua.org 